https://helda.helsinki.fi

\title{
Microbiological spoilage and contamination of vacuum-packaged cooked sausages
}

\author{
Korkeala, Hannu \\ International Association for Food Protection \\ 1997
}

Journal of food protection. 1997. 60(6): 724-731.

http://hdl.handle.net/1975/604

Downloaded from Helda, University of Helsinki institutional repository.

This is an electronic reprint of the original article.

This reprint may differ from the original in pagination and typographic detail.

Please cite the original version. 


\title{
Review
}

\section{Microbiological Spoilage and Contamination of Vacuum-Packaged Cooked Sausages}

\author{
HANNU J. KORKEALA* and K. JOHANNA BJÖRKROTH \\ Department of Food and Environmental Hygiene, University of Helsinki, P.O. Box 57; FIN-00014 Helsinki University, Finland
}

(MS\# 96-121: Received 17 May 1996/Accepted 20 September 1996)

\begin{abstract}
Lactic acid bacteria are considered a major component of the microbial population found on various types of vacuum-packaged cooked sausages. Lactobacillus sake and Lactobacillus curvatus have been shown to be common species in these products. $L$. sake seems to form the predominant part of the spoilage population. Lactic acid bacterial growth on the surface of the sausages produces undesirable sensory attributes, such as sour aroma and taste. A specific spoilage phenomenon of commercial significance, characterized by long, stretchy, polysaccharide ropes between sausages or sausage slices, has also been found. L. sake strains play a major role in this spoilage phenomenon as well. Cooking of sausages during manufacturing destroys lactic acid bacteria on the surface of the sausages. Sausages are recontaminated with spoilage lactic acid bacteria mainly during the processing stages after cooking. During the chilling process, product contamination apparently results from exposure to airborne microorganisms. Workers and equipment are among the most likely sources of contamination during packaging and slicing. Spoilage strains originating from raw material may spread to other areas in the production facility (i.e., chill, slicing, and packaging rooms) via the air, workers and equipment. Decontamination methods can be used to prevent the growth of spoilage microorganisms and to extend the shelf life of vacuum-packaged sausages after packaging.
\end{abstract}

Key words: Lactic acid bacteria, Lactobacillus sake, shelf life, sensory changes, decontamination, vacuum packaging, sausage

Sausages are categorized according to the temperature treatment received during processing (81). Cooked sausages belong to a group characterized by heat treatment after formulation. Textures and flavors achieved in processing contribute to the popularity of cooked sausages in many countries. Sausages are consumed in many ways; as main dishes, as snacks, and in combination with other foods such as bread slices. Sausages are produced in small familyoperated plants as well as large-scale manufacturing facili-

\footnotetext{
* Author for correspondence: Tel: +358-9-70849702; Fax: +358-970849718; E-mail: Hannu.Korkeala@Helsinki.Fi
}

ties. The finished product is usually vacuum packaged and is expected to maintain good quality for 2 to 4 weeks. Spoilage of vacuum-packaged cooked sausages prior to the sell-by date can limit distribution options for the product and inflict considerable economic hardship on manufacturers $(46,89)$.

Beef and pork are the main ingredients in cooked sausage. Other ingredients used include adipose tissue, pork skin, organs, water, spices, and extenders such as starches and flours. Additives such as salt, phosphates, citrates, ascorbates, nitrite, glutamate, lactates, and glucono-delta-lactone are also used. Raw materials and additives usage varies from country to country according to their respective legislation.

The preparation of cooked sausages entails many different phases $(68,81)$. Raw materials are chopped and mixed, creating an emulsion. The emulsion is stuffed into either artificial or natural casings. After stuffing, the sausages may be smoked prior to cooking to an internal temperature of 68 to $73^{\circ} \mathrm{C}$. Sausages are chilled, and some types are peeled and/or sliced before packaging. Vacuum-packaging of sausages has become very popular. Advantages of vacuum packages are hygienic handling of sausages, increased shelf life, good labelling possibilities and better decontamination possibilities. Disadvantages include equipment- and materials-related costs, drip formation, poor separation of slices, and packaging waste.

This paper reviews the main bacterial population which causes spoilage and the typical changes observed in vacuumpackaged cooked sausages. Contamination sites of various processing stages and approaches to improve shelf life are also discussed.

\section{POPULATION OF SPOILAGE BACTERIA}

Lactic acid bacteria form the major component of the microbial population on various types of vacuum-packaged cooked sausages $(2,3,10,33,44,56,72,88)$. A great diversity of lactic acid bacteria can be found in different types of spoiled cooked sausages $(12,22,24,44)$.

Reuter $(71,74)$ has characterized lactobacilli isolated from meat products. He divided lactobacilli into different 
groups, calling some groups formed, atypical streptobacteria. These bacterial cells tend to be coccoid in shape and to possess both a lower acid tolerance and growth temperature minimum than typical streptobacteria. Minimum growth temperatures of 4 to $2^{\circ} \mathrm{C}$ have been observed by Reuter (75). Atypical streptobacteria belonging to the species Lactobacillus sake and Lactobacillus curvatus (32) have often been shown to form the most important spoilage population of vacuum-packaged cooked meat products $(11,19,30,44,56$, $57,71,73,74,88$ ). In addition to biochemical tests, chemotaxonomical and molecular biological methods have been used for the characterization of spoilage lactobacilli in recent years $(7,8,9,20,23,24,25,29,32,35,55,65,69,76$, 77). DNA-DNA hybridization experiments have revealed that $L$. sake and $L$. curvatus are well-defined species (35).

Lactobacillus sake forms the largest group in radurised meat (62). Strains of $L$. sake have often been found to form the predominant part of the spoilage population in vacuumpackaged cooked sausages $(19,22,30,44,88)$. L. sake is also the main cause of a highly offensive and commercially important specific spoilage phenomenon and it seems to be the most important spoilage strain in vacuum-packaged sausages $(46,55)$.

In addition to atypical streptobacteria, obligate heterofermentative lactobacilli and leuconostocs have been found in vacuum-packaged sausages $(11,12,13,24,44,72,73,88)$. Recently, the taxonomic status of these species has been clarified $(15,28)$. Lactobacillus alimentarius and Weissella viridescens (former Lactobacillus viridescens) have occasionally been observed to form the main spoilage populations in Swedish ring sausages $(12,13)$. DNA-DNA hybridization has shown Leuconostoc mesenteroides subsp. mesenteroides, Leuconostoc paramesenteroides and Leuconostoc gelidum (former Leuconostoc amelibiosum) constitute the spoilage strains $(22,55)$. Absence of Carnobacterium spp. from spoiled vacuum-packed vienna sausages was found by von Holy et al. (88).

Species of Enterobacteriaceae, Brochothrix thermosphacta, yeast and mold counts have generally been found to be very low in whole sausages $(10,12,13,40,59,88)$. However, high counts of species of Enterobacteriaceae and especially Brochothrix thermosphacta were found in sliced vacuum-packaged bologna-type sausages (61). In addition to lactic acid bacteria the growth of $B$. thermosphacta was found to adversely affect the shelf life of vacuum-packaged vienna sausages (58). It has been shown that the growth of lactic acid bacteria can limit the growth of $B$. thermosphacta $(16,58)$.

\section{SPOILAGE OF SAUSAGES}

It is generally known that lactic acid bacteria can produce sensory changes as well as changes in physical appearance in spoiled vacuum-packaged sausages (Table 1). Korkeala et al. (37) have studied the mechanism of sensory spoilage in vacuum-packaged cooked ring sausages. Sensory changes are produced by lactic acid bacterial growth on the surface of the sausages $(37,40,41,42,89)$. In addition to the sensory changes in the sausages, changes in the drip
TABLE 1. Types of spoilage of vacuum-packaged cooked sausages

\begin{tabular}{lcc}
\hline Spoilage type & Detection & Cause \\
\hline Acidity & $\begin{array}{c}\text { Sensory analysis } \\
\text { (sour) } \\
\text { pH }\end{array}$ & $\begin{array}{c}\text { Various lactic acid } \\
\text { bacteria }\end{array}$ \\
$\begin{array}{c}\text { White liquid, } \\
\text { slime }\end{array}$ & $\begin{array}{c}\text { Visual inspection } \\
\text { (appearance) }\end{array}$ & $\begin{array}{c}\text { Various lactic acid } \\
\text { bacteria }\end{array}$ \\
Gas formation & $\begin{array}{c}\text { Visual inspection } \\
\text { (loosening of }\end{array}$ & $\begin{array}{c}\text { Heterofermentative } \\
\text { lactobacilli, leuco- }\end{array}$ \\
& packages) & nostocs \\
Ropiness & Visual inspection & Lactobacillus sake, Leu- \\
& (ropy slime) & conostoc gelidum \\
\hline
\end{tabular}

formed inside of packages are observed during storage as well. Special forms of spoilage which adversely affect the appearance of the sausages are slime or ropy slime formation on the sausage surfaces.

Sensory changes produced by lactic acid bacteria appear much later than the time when the bacteria reach the stationary growth phase $(36,37,72)$. The length of time before spoilage changes become detectable increases as the storage temperature decreases (37). We can still see interpretations in which sensory changes in vacuum-packaged cooked sausages are not linked with bacterial numbers of the product (82). These instances of confusion may occur if the spoilage delay is not considered, and sensory changes are attributed to bacterial growth inside the sausages, rather than on the sausage surfaces.

\section{Sourness}

Spoilage lactic acid bacteria produce mostly lactic and acetic acid during logarithmic growth and especially at the stationary phase of growth $(33,74)$. As the counts of lactobacilli reach $5 \times 10^{7} \mathrm{CFU} / \mathrm{g}$ of the surface layer, lactic acid concentration increases sharply (38). Sour aroma and taste are the main undesirable sensory qualities produced as a result of spoilage of vacuum-packaged cooked sausages $(37,42,72,88)$. Deterioration of desirable sensory qualities can be detected more easily by evaluating the skin of the warm sausages (39). Korkeala et al. (37) studied sensory changes as a function of lactobacilli counts in vacuumpackaged cooked ring sausages and found that taste and aroma scores decreased sharply from a constant level when the lactobacilli counts reached $1.4 \times 10^{7} \mathrm{CFU} / \mathrm{g}$. The taste panel considered the samples unfit for human consumption when the number of lactobacilli was between $10^{7}$ and $10^{8}$ $\mathrm{CFU} / \mathrm{g}$. Most samples with a level of $10^{8} \mathrm{CFU} / \mathrm{g}$ were deemed unfit.

The $\mathrm{pH}$ of cooked sausages ranges between 6.0 and 6.5 . In cooked ring sausages, the $\mathrm{pH}$ was initially found to be ca. 6.3. Once the lactic acid bacteria reached a population of $6 \times 10^{7} \mathrm{CFU} / \mathrm{g}$, the $\mathrm{pH}$ decreased sharply $(38,41)$. Samples were deemed spoiled when the $\mathrm{pH}$ fell below 5.8 to 5.9 (38). Low $\mathrm{pH}$ values from 4.6 to 5.5 are found only when sausages are found to be especially spoiled. In vacuumpackaged vienna sausages, the mean $\mathrm{pH}$ values decreased from 6.1 (unspoiled samples) to 4.8 to 4.6 (spoiled samples) (88). In frankfurter sausages, only slight decreases in $\mathrm{pH}$ 
values were observed when transverse slices of sausages after storage in vacuum packages were studied $(10)$.

At $2{ }^{\circ} \mathrm{C}$ spoilage did not always seem to be microbiologi$\mathrm{cal}$, and sausages were deemed spoiled without any marked increase in microbial counts (37). In such cases, the samples developed a musty aroma and taste, rather than sourness. No $\mathrm{pH}$ changes were observed. The lactic acid bacteria population on the sausage after packaging can be so low that the contaminating population may not include strains which are able to grow at $2^{\circ} \mathrm{C}$.

\section{Gas formation}

The increase in $\mathrm{CO}_{2}$ concentration found in packages during storage can be attributed to metabolic by-products of the heterofermentative lactobacilli and leuconostocs $(1,40$, 41,88 ). The aged packages become loose due to the gas formation. Blickstad and Molin (10) found a $\mathrm{CO}_{2}$ concentration up to $21 \%$ in vacuum-stored frankfurter sausages. Gas composition, especially $\mathrm{CO}_{2}$ measurements, of vacuum packages can be used for spoilage detection. The $\mathrm{CO}_{2}$ concentration in vacuum packages has been shown to be initially constant, under $10 \%$, but increases sharply, to 40 to $60 \%$, as lactobacilli exceed $6.4 \times 10^{6} \mathrm{CFU} / \mathrm{g}(41)$.

\section{Slime and gray liquid}

Accumulation of slime and milky fluid in the packages of the sausages during vacuum storage has been observed (33). In some cases the slime formation has been very copious and the product was judged to be unacceptable (12). The amount of drip in the packages increased with storage time (1). Lactic acid formed in the packages changed the appearance of drip from transparent to white or gray (1). The mean exudate volume per $\mathrm{kg}$ of sausages has been found to be $35 \mathrm{ml}(88)$.

\section{Ropy slime formation}

A high incidence of formation of ropy slime on vacuum-packaged cooked sausages was observed in Finland during the 1980 s $(43,46)$. The problem still occurs sporadically. Ropy slime often forms prior to the sell-by date when the bacteria are still in the logarithmic growth phase and before the $\mathrm{pH}$ of the product decreases. The stretchy ropy slime forms long undesirable polysaccharide ropes between sausages and/or sausage slices making the appearance clearly different from a slimy bacterial mass (Fig. 1).

Five groups of lactic acid bacteria have been shown to cause the formation of ropy slime $(8,46,53,55)$. On the basis of DNA-DNA homology, four of these groups contain Lactobacillus sake strains, while only one strain of Leuconostoc gelidum (former Leuconostoc amelibiosum) formed the fifth group (55). L. sake strains belonging to group 1 are the most important contributors to the ropy slime formation $(8,49)$.

Ropy slime-producing strains do not survive the cooking of the sausages to an internal temperature of $68^{\circ} \mathrm{C}(52)$. Contamination of sausages by ropy slime-producing lactic acid bacteria occurs after cooking, during chilling, handling, slicing, and packaging $(48,49,55)$. Quaternary ammonium compounds and acid sanitizers with hydrogen peroxide were

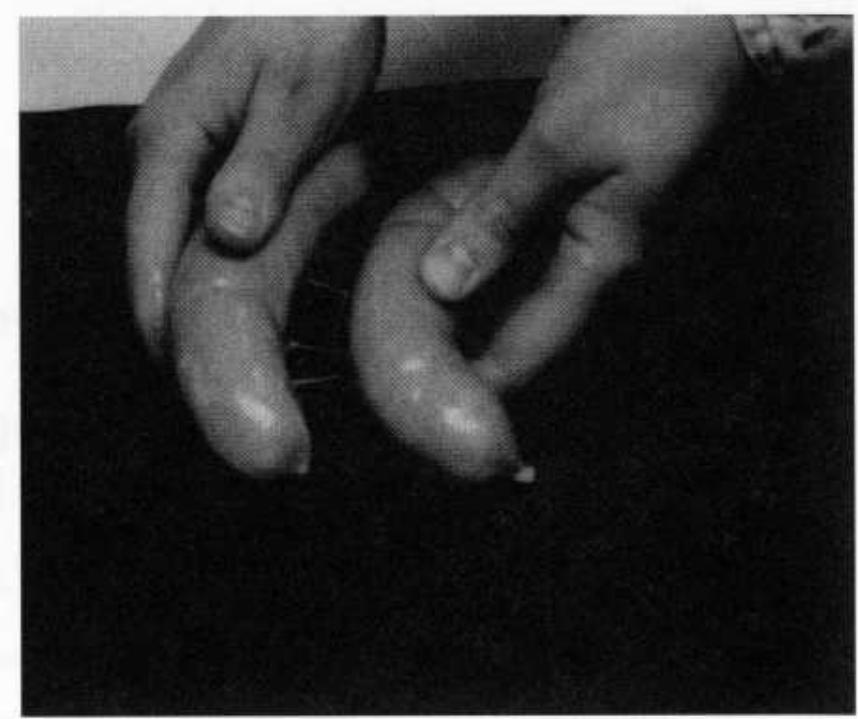

FIGURE 1. Stretchy, undesirable polysaccharide ropes between sausages after storage in vacuum packages.

effective against these strains and can be used for their control (54).

\section{MICROBIOLOGICAL CONTAMINATION OF THE PRODUCTS}

\section{Survival of spoilage bacteria during heat treatment}

The number of lactic acid bacteria on the surface of the sausages is generally very low immediately after processing. Mäkelä and Korkeala (50) found the skins of cooked ring sausages to be relatively free of lactobacilli after cooking, with only 2 out of 30 samples showing the presence of 1 organism per $10 \mathrm{~g}$ of skin. As cooking destroys lactobacilli on the skin of the sausages, spoilage mainly results due to contamination after cooking $(21,50)$. Borch et al. (13) reported that Weissella viridescens was able to survive the sausage cooking process and thus its ability to spoil the heated products was not due to postheating recontamination. The heat-tolerant $W$. viridescens population was considered a major hygienic problem (13).

Korkeala and Lindroth (40) and Mäkelä et al. (52) found that bacteria surviving the heat-treatment process at the center of the sausages were unable to reach high counts during storage for 28 days at $8^{\circ} \mathrm{C}$. Low bacterial counts at the center of the sausage compared to high counts on surface are apparently attributable to differences in microenvironments, especially $a_{w}$.

\section{Recontamination}

Contamination of vacuum-packaged cooked sausages during postheating treatment preparation is presented in Fig. 2. Sausages are recontaminated with lactobacilli during various processing steps after cooking. Contamination studies of various cooked sausages have implicated cold-storage rooms, slicing, and packaging rooms as critical points of bacterial recontamination $(50,56,59)$.

Lactic acid bacteria have been found in the air and on the structural and working surfaces of chill rooms and 


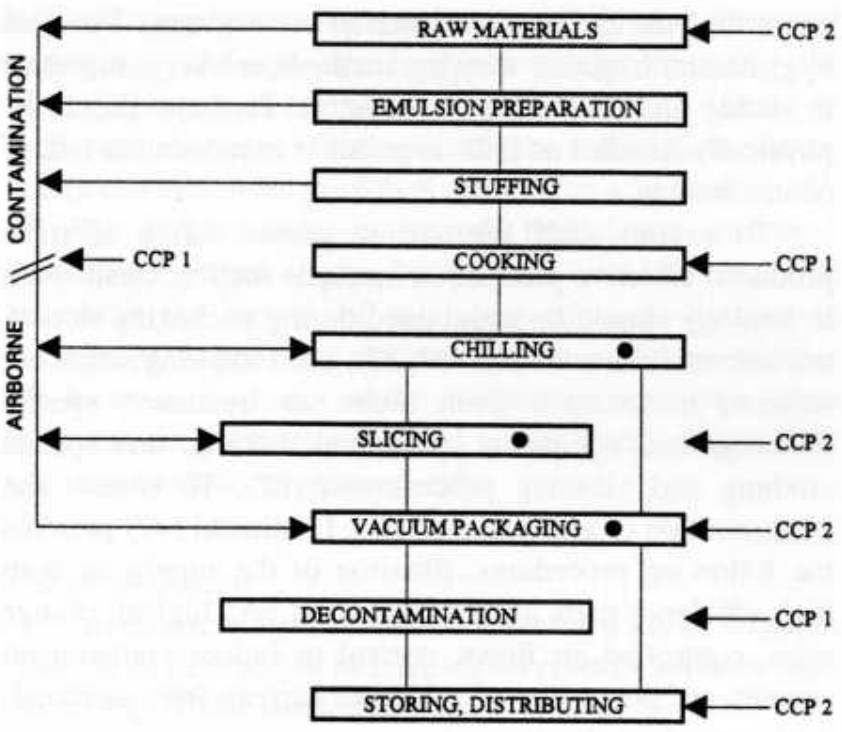

- = A SITE OF MANOR AIRBORNE AND SLRFACE CONTAMINATION

FIGURE 2. Flow diagram for the production of vacuum-packaged cooked sausages. CCP1 is an effective critical control point. CCP2 is not absolute.

packaging rooms, indicating that these locations may act as sources of lactic acid bacteria contamination (50). During the chilling process, contamination of sausage products is mainly from the air. During packaging and slicing, the most likely sources are the workers and equipment $(21,33,50$, 56).

Previously quantitative bacterial determinations have been used to identify recontamination sources. Molecular biological approaches have also been applied to gain greater understanding of the factors affecting recontamination. Using plasmid profiling, Dykes et al. (20) was unable to find associations between lactic acid bacteria isolated from spoiled vacuum-packaged vienna sausages and isolates from processing plants. Björkroth and Korkeala (7) were able to show, by ribotyping, that a Lactobacillus sake starter strain was not the major cause for initiating spoilage of vacuumpackaged sliced cooked meat products which were handled in the same room as fermented products.

\section{Origin of contaminating bacteria}

Mäkelä et al. (51) found that raw materials used in cooked ring sausages can act as a source of spoilage lactic acid bacteria. The highest lactic acid bacterial counts were found in pork skin emulsions and meat trimmings. These raw materials contained isolates which were shown to be associated with spoilage $(40,44)$. Spoilage strains originating from raw materials may spread to chill rooms, slicing, and packaging rooms by the air, workers, and equipment. However, the exact routes of contamination are not clear. The future challenge will be the detection of the origin of lactic acid bacterial strains associated with spoilage. Molecular typing methods can be used for recognition of spoilage strains from cooked meat products. By showing the clonal association between strains isolated from different produc- tion stages with spoilage strains, information concerning recontamination can be obtained.

\section{ESTIMATION OF SHELF LIFE}

Long shelf lives of processed meat products are expected for economic reasons. Vacuum packaging increases the shelf life of sausages when low-oxygen-permeability films are used. By using gas-impermeable packaging materials, the growth of aerobic spoilage microorganisms is inhibited, so that shelf-life sell-by dates of products can be extended $(2,26,60,86)$. Many film types can be used for packaging of meat products. A popular material is a laminate, which contains a gas-tight polyamide and a sealable polyethylene layer. Oxygen-barrier properties can be improved through the selection of various packaging materials currently available. However, a significantly longer shelf life may not be achieved by using high-barrier films instead of traditional laminates (4).

The shelf life of various sausages, based on sensory evaluation, are presented in Table 2. Depending on storage temperature, sensory changes were usually detected in vacuum-packaged cooked sausages in 2 to 7 weeks. Blickstad and Molin (10), however, did not find any off odors even after 98 days of storage of vacuum-packaged frankfurter sausages at $4^{\circ} \mathrm{C}$.

The extent of Lactobacillus contamination of cooked sausages can vary considerably from plant to plant. This variability creates an inconsistent shelf life for the same product(s) produced in different plants (50). However, the storage temperature has been found to be the most critical factor affecting shelf life. When the initial bacterial contamination level is the same for products, the shelf life has been found to depend only on temperature. The mathematical formula given by Sinell (84) predicts the shelf life as a function of temperature only, making it possible to calculate the shelf life of a product $(D)$ at a certain temperature $(t)$, providing the shelf life of the product is known for some other

TABLE 2. Shelf life times based on sensory evaluation of vacuumpackaged cooked sausages stored at different temperatures

\begin{tabular}{lccc}
\hline \multicolumn{1}{c}{ Sausage } & $\begin{array}{c}\text { Shelf life } \\
\text { (days) }\end{array}$ & $\begin{array}{c}\text { Storage } \\
\text { temperature } \\
\left({ }^{\circ} \mathrm{C}\right)\end{array}$ & Reference \\
\hline Wiener & 14 & 6 & $(3)$ \\
Bologna & 6 & 15 & \\
& 14 & 3 & $(3)$ \\
Vienna & 8 & 6 & \\
Frankfurter & 2 & 15 & \\
Bologna & $10-30$ & 8 & $(58)$ \\
Emulsion type & 98 & 4 & $(10)$ \\
$\quad$ (ring sausage) & $27-29$ & 4 & $(4)$ \\
Ring sausage & 26 & 4 & $(12)$ \\
& 55 & 2 & $(40)$ \\
& 43 & 4 & \\
Vienna & 29 & 8 & \\
\hline
\end{tabular}


temperature. The formula is as follows: $D=D_{0} \times 10^{\left(t_{0}-t\right) / 20}$, where $D_{0}$ is the shelf life at a known temperature, $t_{0}$.

Using both sensory and microbiological criteria for evaluation, Sinell's (84) formula accurately estimated the shelf life of vacuum-packaged cooked ring sausages (36). Korkeala et al. (37) formulated the dependence of the shelf life of vacuum-packaged cooked ring sausages on storage temperature $t_{\mathrm{s}}$ as follows: Shelf life $=10^{\left(1.835-0.048 \times t_{\mathrm{s}}\right)}$. The maximal shelf life of this product is estimated to be about 10 to 11 weeks.

\section{FACTORS AFFECTING SHELF LIFE}

To extend the shelf life of vacuum-packaged processed meat products, three approaches can be used: (i) reduction of microbial contamination during production, (ii) growth prevention of spoilage bacteria, and (iii) application of decontamination procedures to products after packaging. The methods currently available are presented in Table 3 .

\section{Prevention of microbiological contamination}

To prevent microbiological contamination, production hygiene must be improved. Factors to consider include design of the production environment, such as air conditioning, material flow, equipment, cleaning procedures, and personal hygiene of the food handlers.

Cooked-sausage surfaces can be considered essentially sterile after cooking. Cold-storage areas and slicing and packaging areas are the most significant sites for microbiological contamination (Fig. 2). Bacteria from raw materials must be prevented from being transferred to other rooms where the products are handled after cooking $(51,53)$. To avoid contamination by potential spoilage bacteria, processing rooms for cooked products should be separated from rooms where raw meat is handled. The slicing and packaging of cooked sausages should be separated from the rooms where fermented sausages are handled, as well. Fermented products can be potential sources of spoilage lactic acid bacteria (48).

Closed lines, where ovens separate clean areas from unclean areas, are recommended. Ovens are loaded with the raw product in unclean areas and cooked products are unloaded in the clean area of the processing line. The material flow and staff travel should be designed to prevent the spread of contamination from the unclean areas to clean areas. Positive pressure should be used in clean areas,

TABLE 3. Processes which affect the shelf life of vacuumpackaged meat products

\begin{tabular}{ll}
\hline \multicolumn{1}{c}{ Phase of the process } & \multicolumn{1}{c}{ Treatment } \\
\hline The formula & The use of food additives \\
Cooking & Adequate cooking temperatures \\
Slicing and packaging & Production hygiene \\
& Clean room technology \\
& Biopreservation \\
After packaging & Irradiation \\
& Pasteurization \\
& Microwave treatment \\
\hline
\end{tabular}

controlling the air flow from unclean to clean areas. Personal hygiene and hygienic working methods are very important in slicing and packaging departments. Products should be physically handled as little as possible to reduce the risk of contamination.

To extend shelf life and to ensure safety of meat products, effective production methods such as clean-room technology should be maintained during packaging to control airborne contaminants $(47,87)$. The following stages are required to create a clean room: air treatment, special buildings and equipment, personnel training, and special clothing and cleaning procedure(s) (87). To control the concentration of airborne particles, Lehtimäki (47) presents the following procedures: filtration of the supply air with high-efficiency particulate air filters (HEPA), high air change rates, controlled air flows, control of indoor contaminant sources, and prevention of leaking air currents from surroundings rooms into clean rooms.

Van Zuijlen (87) considered clean-room packaging the most difficult aspect of production due to requirements for the absence of recontamination when meat products are packaged by hand. The number of bacteria on product surfaces were found to be lower on products produced in high-care departments when compared to old packaging departments (87). Information concerning shelf life of products packed in clean rooms is not yet available. Since clean-room technology lowers the amount of competitive bacteria, these products may also provide better growth conditions for pathogenic bacteria in a production-failure situation.

\section{Inhibition of bacterial growth}

Low storage temperatures effectively decrease the growth of the spoilage lactic acid bacteria. However, the minimum growth temperatures of these bacteria are very low. Korkeala et al. (45) found that all ropy slime-producing $L$. sake strains were able to multiply on MRS agar at temperatures below $0^{\circ} \mathrm{C}$. Hence, the growth of spoilage lactic acid bacteria cannot be inhibited completely by the use of low temperatures only.

Concentrations of salt and nitrite used in the manufacturing of cooked sausages are not effective in inhibiting the growth of spoilage lactic acid bacteria $(2,39,56)$. Nevertheless, significant negative correlations have been found between concentrations of nitrite and bacterial counts after 2 weeks of storage. These correlations were not found between initial nitrite concentrations and counts after 2 weeks (83). Sodium chloride combined with nitrite in low concentrations has produced inhibitory effects on the growth of a spoilage population. Leuconostocs are more sensitive to $\mathrm{NaCl}$ and $\mathrm{NaNO}_{2}$ than homofermentative lactobacilli. Lactobacillus curvatus strains are more sensitive to $\mathrm{NaCl}$ and $\mathrm{NaNO}_{2}$ than Lactobacillus sake strains (39). Two percent sodium lactate was shown to inhibit the growth of lactic acid bacteria and thus to increase the shelf life of vacuumpackaged coarse liver paté and beef bologna $(14,17)$.

The concept of a competitive bacterial population has gained popularity and is being employed $(63,64,66)$. Biopreservation (protective cultures) employs the applica- 
tion of living bacteria on products to inhibit the growth of pathogenic and spoilage bacteria without changing the sensory properties of the products (5). Certain strains of lactic acid bacteria excrete substances called bacteriocins, which can inhibit the growth of other lactic acid bacteria (67, 79,80 ). As knowledge concerning bacteriocins increases, protective cultures or pure bacteriocins could be employed to inhibit the growth of spoilage lactic acid bacteria in vacuum-packaged meat products. Because of their specificity, bacteriocins do not inhibit all spoilage organisms. They may also be inactivated by food constituents, making their use very product-category specific.

\section{Decontamination}

An effective technique to increase shelf life of sausages consists of destruction of bacteria on product surfaces after packaging. These methods are listed in Table 3.

Vacuum-packaged vienna sausages heat treated by immersion of retail packs into water at $80^{\circ} \mathrm{C}$ for $20 \mathrm{~min}$ realized a fourfold increase in shelf life compared to control products kept at $7^{\circ} \mathrm{C}(89,90)$. When cooked grill sausages were vacuum packaged and then heated at a temperature of $95^{\circ} \mathrm{C}$ for $5 \mathrm{~min}$, in a steam cabinet the shelf life of the sausages was improved (52). The same heating broke down the emulsion structure of a sliced sausage product. Sliced sausages present greater challenges with respect to suitable heat treatments than do sausages packed in casings. For vienna sausages, in-package pasteurization increased shelf life but did not eliminate bacterial spoilage $(27,89)$. However, in-package pasteurization may increase clostridial prevalence so that product safety is jeopardized (27). Cooked sausages autoclaved in aluminum packages were found to have a shelf life of 6 to 12 months (34).

Irradiated vacuum-packed bologna samples exposed to a total dose of 0.3 Mrads showed an absence of growth of lactic acid bacteria during a 4-week storage period at $5^{\circ} \mathrm{C}$, whereas lactic acid bacteria counts reached $8 \times 10^{6} \mathrm{CFU} / \mathrm{g}$ after 2 weeks in nonirradiated control samples (16). Irradiation with a dose of $2 \mathrm{kGy}$ increased shelf life of sliced cooked sausages, but also produced off flavors described as soapy, metallic, plastic-like, chemical, or musty (85). Microwave heat treatment was shown to reduce the concentrations of various bacteria inoculated onto sliced cooked sausages (78). However, the effect was limited with lactic acid bacteria, compared to other bacteria tested.

In the future, new packaging and decontamination techniques may be available for extending the shelf life of sausages. Unlike the passive protection of the product by traditional packaging materials and methods, new trends such as active packaging have been introduced $(31,70)$. A series of biocidal films and coatings have been developed for retarding the growth of bacteria and other contaminants. These films and coatings release controlled amounts of the biocide, chlorine dioxide, in response to temperature and humidity changes in the atmosphere.

New decontamination methods have also been developed. Pulsed-light treatment and other nonthermal methods have been introduced for killing microorganisms $(6,18)$. This technique employs intense, bactericidal flashes of sunlight-like light which can be applied to the product surfaces before or after packaging, when UV-permeable films are used. The development and application of these new techniques will be an important challenge for future research.

\section{REFERENCES}

1. Ahvenainen, R., R.-L. Kivikataja, and E. Skyttä. 1990. Factors affecting the shelf-life of gas and vacuum-packed cooked meat products. Part II: Vienna sausages. Lebensm. Wiss. Technol. 23:130138.

2. Allen, J. R., and E. M. Foster. 1960. Spoilage of vacuum-packed sliced processed meats during refrigerated storage. Food Res. 25:1925.

3. Alm, F., I. Erichsen, and N. Molin. 1961. The effect of vacuum packaging on some sliced processed meat products as judged by organoleptic and bacteriological analysis. Food Technol. 15:199-203.

4. Andersen, F. 1989. Shelf life of vacuum packed bologna type sausage as affected by oxygen permeability, initial count and storage temperature, p. 400-402. In Proceedings of the 34th International Congress of Meat Science and Technology, Copenhagen.

5. Andersen, L. 1995. Preservation of meat products with a lactic acid bacteria culture-FloraCarn L-2, p. 303-304. Proceedings of the 41st International Congress of Meat Science and Technology, vol. II.

6. Barbosa-Cánovas, G. 1996. Non thermal electrical pasteurization methods, p. 59-69. In T. Ohlsson, R. Ahvenainen, and T. MattilaSandholm (ed.), Minimal processing and ready made foods. Proceedings of the International Symposium. Swedish Institute for Food and Biotechnology, Gothenburg.

7. Björkroth, J., and H. Korkeala. 1996. Evaluation of Lactobacillus sake contamination in vacuum-packaged sliced cooked meat products by ribotyping. J. Food Prot. 59:398-401.

8. Björkroth, J., and H. Korkeala. 1996. rRNA gene restriction patterns as a characterization tool for Lactobacillus sake strains producing ropy slime. Int. J. Food Microbiol. 30:293-302.

9. Björkroth, J., J. Ridell, and H. Korkeala. 1996. Characterization of Lactobacillus sake strains associating with production of ropy slime by randomly amplified polymorphic DNA (RAPD) and pulsed-field gel electrophoresis (PFGE) patterns. Int. J. Food Microbiol., 31: 59-68.

10. Blickstad, E., and G. Molin. 1983. The microbial flora of smoked pork loin and frankfurter sausage stored in different gas atmospheres at $4^{\circ}$ C. J. Appl. Bacteriol. 54:45-56.

11. Borch, E., and G. Molin. 1988. Numerical taxonomy of psychrotrophic lactic acid bacteria from prepacked meat and meat products. Antonie van Leeuwenhoek 54:301-323.

12. Borch, E., and E. Nerbrink. 1989. Shelf-life of emulsion sausage stored in vacuum or modified atmospheres, p. 470-477. Proceedings of the 34th International Congress of Meat Science and Technology, Copenhagen.

13. Borch, E., E. Nerbrink, and P. Svensson. 1988. Identification of major contamination sources during processing of emulsion sausage. Int. J. Food Microbiol. 7:317-330.

14. Brewer, M. S., F. McKeith, S. E. Martin, A. W. Dallmier, and S. Y. Wu. 1992. Some effects of sodium lactate on shelf-life, sensory, and physical characteristics of vacuum-packaged beef bologna. J. Food Qual. 15:369-382.

15. Collins, M. D., U. M. Rodrigues, C. Ash, M. Aguirre, J. A. E. Farrow, A. Martinez-Murcia, B. A. Phillips, A. M. Williams, and S. Wallbanks, 1991. Phylogenetic analysis of the genus Lactobacillus and related lactic acid bacteria as determined by reverse transcriptase sequencing of 16S rRNA. FEMS Microbiol. Lett. 77:5-12.

16. Collins-Thompson, D. L., and G. R. Lopez. 1982. Control of Brochothrix thermosphacta by Lactobacillus species in vacuum packed bologna. Can. Inst. Food Sci. Technol. J. 15:307-309.

17. Debevere, J. M. 1989. The effect of sodium lactate on the shelf life of vacuum-packed coarse liver pate. Fleischwirtschaft 69:223-224.

18. Dunn, J., T. Ott, and W. Clark. 1995. Pulsed-light treatment of food and packaging. Food Technol. 49(9):95-98. 
19. Dykes, G. A., T. J. Britz, and A. von Holy. 1994. Numerical taxonomy and identification of lactic acid bacteria from spoiled, vacuumpackaged vienna sausages. J. Appl. Bacteriol. 76:246-252.

20. Dykes, G. A., A. Y. Burgess, and A. von Holy. 1993. Plasmid profiles of lactic acid bacteria associated with vacuum-packaged vienna sausage manufacture and spoilage. Lett. Appl. Microbiol. 17:182184.

21. Dykes, G. A., T. E. Cloete, and A. von Holy. 1991. Quantification of microbial populations associated with the manufacture of vacuumpackaged, smoked vienna sausages. Int. J. Food Microbiol. 13:239 248.

22. Dykes, G. A., T. E. Cloete, and A. von Holy. 1994. Identification of Leuconostoc species associated with the spoilage of vacuumpackaged vienna sausages by DNA-DNA hybridization. Food Microbiol. 11:271-274.

23. Dykes, G. A., T. E. Cloete, and A. von Holy. 1995. Taxonomy of lactic acid bacteria associated with vacuum-packaged processed meat spoilage by multivariate analysis of cellular fatty acids. Int. J. Food Microbiol. 28:89-100.

24. Dykes, G. A., and A. von Holy. 1993. Taxonomy of lactic acid bacteria from spoiled, vacuum packaged vienna sausages by total soluble protein profiles. J. Basic Microbiol. 3:169-177.

25. Dykes, G. A., and A. von Holy. 1994. Taxonomic status of atypical Lactobacillus sake and Lactobacillus curvatus strains associated with vacuum-packaged meat spoilage. Curr. Microbiol. 28:197-200.

26. Egan, A. F., and B. J. Shay. 1982. Significance of lactobacilli and film permeability in the spoilage of vacuum-packaged beef. J. Food Sci. 47:1119-1122, 1126 .

27. Franz, C. M. A. P., and A. von Holy. 1996. Thermotolerance of meat spoilage lactic acid bacteria and their inactivation in vacuumpackaged vienna sausages. Int. J. Food Microbiol. 29:59-73.

28. Hammes, W. P., and R. F. Vogel. 1995. The genus Lactobacillus, p. 19-54, In B. J. B. Wood and W. H. Holzapfel (ed.), The genera of lactic acid bacteria. Blackie Academic and Professional, Glasgow.

29. Hertel, C., W. Ludwig, M. Obst, R. F. Vogel, W. P. Hammes, and K. H. Schleifer. 1991. 23 rRNA-targeted oligonucleotide probes for the rapid identification of meat lactobacilli. Syst. Appl. Microbiol. 14:173-177.

30. Holzapfel, W. H., and E. S. Gerber. 1986. Predominance of Lactobacillus curvatus and Lactobacillus sake in the spoilage association of vacuum-packaged meat products, p. 26. Abstracts of the 32nd European Meeting of Meat Research Workers, Ghent.

31. Hurme, E., and R. Ahvenainen. 1996. Active and smart packaging of ready made foods, p. 169-182. In T. Ohlsson, R. Ahvenainen, and T. Mattila-Sandholm (ed.), Minimal processing and ready made foods. Proceedings of the International Symposium, Swedish Institute for Food and Biotechnology, Gothenburg.

32. Kagermeier, A. 1981. Taxonomie und Vorkommen von Milchsäurebakterien in Fleischprodukten. Thesis, Ludwig-Maximilians-Universität, München.

33. Kempton, A. G., and S. R. Bobier. 1970. Bacterial growth in refrigerated, vacuum-packed luncheon meats. Can. J. Microbiol. 16:287-297.

34. Klare, H. J. 1973. Herstellung haltbarer Brühbratwürste in aluminiumfolienpackungen. Fleischwirtschaft 53:1519-1522.

35. Klein, G., L. M. T. Dicks, A. Pack, B. Hack, K. Zimmermann, F. Dellaglio, and G. Reuter. 1996. Emended descriptions of Lactobacillus sake (Katagiri, Kitahara, and Fukami) and Lactobacillus curvatus (Abo-Elnaga and Kandler): Numerical classification revealed by protein fingerprinting and identification based on biochemical patterns and DNA-DNA hybridizations. Int. J. Syst. Bacteriol. 46:367-376.

36. Korkeala, H., and T. Alanko. 1988. The prediction of food-product shelf-life, p. 537-538. Proceedings of the 34th International Congress of Meat Science and Technology, Part B. Brisbane.

37. Korkeala, H., T. Alanko, P. Mäkelä, and S. Lindroth. 1989. Shelf-life of vacuum-packed cooked ring sausages at different chill temperatures. Int. J. Food Microbiol. 9:237-247.

38. Korkeala, H., T. Alanko, P. Mäkelä, and S. Lindroth. 1990. Lactic acid and $\mathrm{pH}$ as quick indicators of spoilage in vacuum-packed cooked ring sausages. Int. J. Food Microbiol. 10:245-254.

39. Korkeala, H., T. Alanko, and T. Tiusanen. 1992. Effect of sodium nitrite and sodium chloride on growth of lactic acid bacteria. Acta Vet. Scand. 33:27-32.
40. Korkeala H., and S. Lindroth. 1987. Differences in microbial growth in the surface layer and at the centre of vacuum-packed cooked ring sausages. Int. J. Food Microbiol. 4:105-110.

41. Korkeala, H., S. Lindroth, R. Ahvenainen, and T. Alanko. 1987. Interrelationship between different parameters in the spoilage of vacuum-packed cooked ring sausages. Int. J. Food Microbiol. 5:311321.

42. Korkeala, H., S. Lindroth, M. Suihko, A. Kuhmonen, and P.-L. Penttila. 1985. Microbiological and sensory quality changes in blood pancakes and cooked ring sausage during storage. Int. J. Food Microbiol. 2:279-292.

43. Korkeala, H., and P. Mäkelä. 1988. Tyhjiöpakattujen lihavalmisteiden limaantuminen săilytyksen aikana. Suom. Elăinlääkäril. 94:292-294.

44. Korkeala, H., and P. Mäkelä. 1989. Characterization of lactic acid bacteria from vacuum-packed cooked ring sausages. Int. J. Food Microbiol. 9:33-43.

45. Korkeala, H., P. Măkelă, and H. Suominen. 1990. Growth temperatures of ropy slime-producing lactic acid bacteria. J. Food Prot. 53:793-794.

46. Korkeala, H., T. Suortti, and P. Mäkelä. 1988. Ropy slime formation in vacuum-packed cooked meat products caused by homofermentative lactobacilli and a Leuconostoc species. Int. J. Food Microbiol. 7:339-347.

47. Lehtimäki, M. 1994. Clean room technology, p. 119-128. In R. Ahvenainen, T. Mattila-Sandholm, and T. Ohlsson (ed.), Minimal processing of foods. VTT Symposium 142, Technical Research Centre of Finland, Espoo.

48. Mäkelä, P. 1992. Fermented sausage as a contamination source of ropy slime-producing lactic acid bacteria. J. Food Prot. 55:48-51.

49. Mäkelä, P. 1993. Lactic acid bacterial contamination at meat processing plants. Thesis, College of Veterinary Medicine, Helsinki.

50. Mäkelä, P., and H. Korkeala. 1987. Lactobacilli contamination of cooked ring sausage processing plant. Int. J. Food Microbiol. 5:323-330.

51. Mäkelä, P., H. Korkeala, and J. Laine. 1990. Raw materials of cooked ring sausages as a source of spoilage lactic acid bacteria. J. Food Prot. 53:965-968.

52. Mäkelä, P., H. Korkeala, and J. Laine. 1992. Survival of ropy slime-producing lactic acid bacteria in heat processes used in the meat industry. Meat Sci. 31:463-471.

53. Mäkelä, P., H. Korkeala, and J. Laine. 1992. Ropy slime-producing lactic acid bacteria contamination at meat processing plants. Int. J. Food Microbiol. 17:27-35.

54. Mäkelä, P., H. Korkeala, and K. Sand. 1991. Effectiveness of commercial germicide products against the ropy slime-producing lactic acid bacteria. J. Food Prot. 54:632-636.

55. Mäkelä, P., U. Schillinger, H. Korkeala, and W. H. Holzapfel. 1992. Classification of ropy slime-producing lactic acid bacteria based on DNA-DNA homology, and identification of Lactobacillus sake and Leuconostoc amelibiosum as dominant spoilage organisms in meat products. Int. J. Food Microbiol. 16:167-172.

56. Mol, J. H. H., J. E. A. Hietbrink, H. W. M. Mollen, and J. van Tinteren. 1971. Observations on the microflora of vacuum packed sliced cooked meat products. J. Appl. Bacteriol. 34:377-397.

57. Morishita, Y., and K. Shiromizu. 1986. Characterization of lactobacilli isolated from meats and meat products. Int. J. Food Microbiol. 3:19-29.

58. Mukherji, S., and S. Qvist. 1981. The impact of Brochothrix thermosphacta and lactic acid bacteria on the keeping quality of vacuum-packaged vienna sausages, p. 231-239. In T. A. Roberts, E. Hobbs, J. H. B. Christian, and N. Skovgaard (ed.), Psychrotrophic microorganisms in spoilage and pathogenicity. Academic Press, London.

59. Nerbrink, E., and E. Borch. 1993. Evaluation of bacterial contamination at separate processing stages in emulsion sausage production. Int. J. Food Microbiol. 20:37-44.

60. Newton, K. G., and W. J. Rigg. 1979. The effect of film permeability on the storage life and microbiology of vacuum-packed meat. J. Appl. Bacteriol. 47:433-441.

61. Nielsen, H.-J. S. 1983. Influence of temperature and gas permeability of packaging film on development and composition of microbial flora in vacuum-packed bologna-type sausage. J. Food Prot. 46:693698,701 . 
62. Niemand, J. G., and W. H. Holzapfel. 1984. Characteristics of lactobacilli isolated from radurised meat. Int. J. Food Microbiol. 1:99-110.

63. Niinivaara, F. 1955 über den Einfluss von Bakterien-reinkulturen auf die Reifung um Umrötung der Rohwurst. Acta Agralia Fennica $84: 1-128$.

64. Niinivaara, F., and M. Pohja. 1957. Die in der Rohwurst vorkommenden Bakterien und ihre Bedeutung beim Reifung-prozess. Fleischwirtschaft 9:264-268.

65. Nissen, H., and R. Dainty. 1995. Comparison of the use of rRNA probes and conventional methods in identifying strains of Lactobacillus sake and $L$. curvatus isolated from meat. Int. J. Food Microbiol. 25:311-315.

66. Nurmi, E., and M. Rantala. 1973. New aspects of Salmonella infection in broiler production. Nature 241:210-211.

67. Papathanasopoulos, M. A., C. M. A. P. Franz, G. A. Dykes, and A. von Holy. 1991. Antimicrobial activity of meat spoilage lactic acid bacteria. South Afr. J. Sci. 87:243-246.

68. Pearson, A. M., and F. W. Tauber. 1984. Processed meats, 2nd ed. Van Nostrand Reinhold Company Inc., New York.

69. Petrick, H. A. R., R. E. Ambrosio, and W. H. Holzapfel. 1988. Isolation of a DNA probe for Lactobacillus curvatus. Appl. Environ. Microbiol. 54:405-408.

70. Pszczola, D. E. 1995. Packaging takes an active approach. Food Technol. 49(8): 104.

71. Reuter, G. 1970. Laktobazillen und eng verwandte Mikroorganismen in Fleisch und Fleischerzeugnissen. 2. Mitteilung: Die Charakterisierung der isolierten Laktobazillenstämme. Fleischwirtschaft 50: 954-962.

72. Reuter, G. 1970. Untersuchungen zur Mikroflora von verpackten, aufgeschnittenen Brüh- und Kochwürsten. Arch. Lebensmittelhyg. 21:257-264.

73. Reuter, G. 1970. Laktobazillen und eng verwandte Mikroorganismen in Fleisch und Fleischwaren. 4. Mitteilung: Die Ökologie von Laktobazillen, Leuconostoc-Species und Pediokokken. Fleischwirtschaft 50:1397-1399.

74. Reuter, G. 1975. Classification problems, ecology and some biochemical activities of lactobacilli of meat products, p. 221-229. In J. C. Can, C. V. Cutting, and G. C. Whiting (ed.), Lactic acid bacteria in beverages and food. Academic Press, London.

75. Reuter, G. 1981. Psychrotrophic lactobacilli in meat products, p. 253-258. In T. A. Roberts, E. Hobbs, J. H. B. Christian, and N. Skovgaard (ed.), Psychrotrophic microorganisms in spoilage and pathogenicity. Academic Press, London.

76. Rizzo, A. F., H. Korkeala, and I. Mononen. 1987. Gas chromatography analysis of cellular fatty acids and neutral monosaccharides in the identification of lactobacilli. Appl. Environ. Microbiol. 53:28832888.
77. Samelis, J., E. Tsakalidou, J. Metaxopoulos, and G. Kalantzopoulos. 1995. Differentation of Lactobacillus sake and Lact. curvatus isolated from naturally fermented Greek dry salami by SDS-PAGE of whole cell proteins. J. Appl. Bacteriol. 78:157-163.

78. Schalch, B., H. Eisgrüber, and A. Stolle. 1994. Eignung der Mikrowellenbehandlung zur Keimzahlreduzierung bei vakuumverpacktem Brühwurstaufschnitt. Arch. Lebensmittelhyg. 45:6-13.

79. Schillinger, U., and F.-K. Lücke. 1989. Einsatz von Milchsäurebakterien als Schutzkulturen bei Fleischerzeugnissen. Fleischwirtschaft 69:1581-1585.

80. Schillinger, U., and F.-K. Lücke. 1989. Antibacaterial activity of Lactobacillus sake isolated from meat. Appl. Environ. Microbiol. 55:1901-1906.

81. Schmidt, G. R. 1988. Processing, p. 83-114. In H. R. Cross and A. J. Overby (ed.), Meat science, milk science and technology. Elsevier Science Publishing Company, New York.

82. Sheridan, J. J. 1995. Shelf-life and safety of cured, cooked pork products, p. 125-152. In J. Lenges, M. Casteels, L. Deweghe, and T. Nicolai (ed.), Curing technology for cooked pig meat products; an update, ECCEAMST Foundation, Utrecht.

83. Silla, H., and B. Simonsen. 1985. Shelf-life of cured, cooked and sliced meat products. I. Influence of composition, vacuum packaging and modified atmospheres. Fleischwirtschaft 65:66-69, 116-121.

84. Sinell, H.-J. 1980. Einführung in die Lebensmittelhygiene. Verlag Paul Parey, Berlin.

85. Stekelenburg, F. K. 1990. Irradiation of pre-packaged sliced cooked meat products with low and normal sodium content. Int. J. Food Microbiol. 10:23-32.

86. Vanderzant, C., M. O. Hanna, J. G. Ehlers, J. W. Savell, G. C. Smith, D. B. Griffin, R. N. Terrell, K. D. Lind, and D. E. Galloway. 1982. Centralized packaging of beef loin steaks with different oxygenbarrier films: microbiological characteristics. J. Food Sci. 47:10701079.

87. Van Zuijlen, A. 1995. High care production: sense and nonsense, p. 75-88. In S. A. Burt, and F. Bauer (ed.), New challenges in meat hygiene: specific problems in cleaning and disinfection. ECCEAMST Foundation, Utrecht.

88. von Holy, A., T. E. Cloete, and W. H. Holzapfel. 1991. Quantification and characterization of microbial populations associated with spoiled, vacuum-packed vienna sausages. Food Microbiol. 8:95-104.

89. von Holy, A., and W. H. Holzapfel. 1989. Spoilage of vacuum packaged processed meats by lactic acid bacteria, and economic consequences, p. 185-190. Proceedings of the 10th International Symposium of the World Association of Veterinary Food Hygienists, Stockholm

90. von Holy, A., D. Miessner, and W. H. Holzapfel. 1991. Effects of pasteurization and storage temperature on vacuum-packaged vienna sausage shelf-life. South Afr. J. Sci. 87:387-390. 